\title{
Brazil and Indonesia: A Study On Civics
}

Asha Wiratnanto

April 13th 2021 


\section{Table of contents}

$\begin{array}{ll}\text { Introduction } & 3\end{array}$

$\begin{array}{ll}\text { Methodology } & 3\end{array}$

Research Method $\quad 3$

Profile of Interviews (Indonesia) $\quad 4$

Profile of Interviews (Brazil) $\quad 4$

$\begin{array}{ll}\text { Analysis } & 4\end{array}$

Research Findings in Indonesia $\quad 5$

What is civics? $\quad 5$

Civics in Indonesia $\quad 5$

History in Indonesia $\quad 5$

Historical Event that helped shape civics in Indonesia $\quad 6$

$\begin{array}{ll}\text { Suharto's leadership regime } & 7\end{array}$

Structure of the Indonesian State $\quad 8$

Official Legal Instrument - Indonesia $\quad 9$

$\begin{array}{lr}\text { Political Participation } & 9\end{array}$

$\begin{array}{ll}\text { Public Participation for an Indonesian citizen } & 10\end{array}$

Importance of Political Participation for people to engage from an Indonesian citizen 11

Effect of Pandemic on Civics in Indonesia $\quad 12$

Civics in Indonesia by $2050 \quad 13$

Research Findings in Brazil $\quad 13$

What is civics? 13

Civics in Brazil $\quad 14$

History in Brazil 14

Historical Event that helped shape civics in Brazil 14

Describing The Period Between 1964-1985 15

$\begin{array}{ll}\text { Structure Of The Brazilian State } & 15\end{array}$

Official Legal Instrument - Brazil 16

Political Participation 16

$\begin{array}{ll}\text { Public Participation for a Brazilian Citizen } & 17\end{array}$

Importance of Political Participation for people to engage from a Brazilian citizen 17

$\begin{array}{ll}\text { Effect of Pandemic on Civics in Brazil } & 18\end{array}$

Civics in Retrospect $\quad 18$

Civics in Brazil by $2050 \quad 19$

$\begin{array}{lr}\text { Conclusion } & \mathbf{2 0}\end{array}$ 


\section{Introduction}

This report investigates the meaning of civics in Indonesia and Brazil and what it means for Indonesian and Brazilian citizens for the elective of Comparative Civics. This report is to collect the findings of different perspectives of what civics means to individual Indonesian and Brazilian citizens. Previously reading the UUD 1945 Constitution of Indonesia and the Constituição do Brasil of 1988, I got good background knowledge on the information to come about the civil duties for an Indonesian and Brazilian citizen.

In the following report, I will illustrate the methodology which I used to conduct the interviews. Then, I shall describe and analyse the research findings based on the questions asked in the interviews, finally followed by a final conclusion.

\section{Methodology}

\section{Research Method}

By using the following Interview Script for this report, I decided to conduct five interviews with Indonesian citizens discussing their point of view on civics in Indonesia. Following this, I decided to conduct three interviews with Brazilian citizens exploring their opinion on civics in Brazil. Using the platform Zoom, I was able to record, listen, and while taking notes, I saved each interview conducted which approximately took one hour each. Each interviewee's name has been aligned with typical anthropological processes by using pseudonyms to preserve the interviewer's identity. 


\section{Profile of Interviews (Indonesia)}

The first interviewee was Scarlett O’Brien. A 16 year old Indonesian student, studying in a public school in Indonesia. Following Priscilla, a +-39 year old Indonesian who is a full time junior researcher in the National Institute of Public Administration (NIPA). Then, Yulissa Hoffman, a 41 year old Indonesian working 16 years in the Ministry of Foreign Affairs. Subsequently, Jerald Anderson, a +-39 year old Indonesian working in the private sector. And finally Ryan, a +-42 year old Indonesian working to the United Nations.

Profile of Interviews (Brazil)

The following batch of interviewees were Brazilians! The first interviewee was Margherita Rose Vaughn. An educator in the American School Of Rio De Janeiro. Following was Titus Nichols, a 16 year old student studying in an international school in Brazil. Following Valerie Miller who in place of an actual interview, kindly gave a written script about the interview.

Analysis

Following the interviews, I used the platform Google Sheets to digitally transfer the main points from each question asked. Thus, I was able to analyse, compare and contrast each of the rich information filled answers from the interviewees by using the following Interview Matrix. 


\section{Research Findings in Indonesia}

What is civics?

The interviewees generally agreed that civics is defined by the rights and obligations of a citizen where they have their own fairshare to contribute to something and to obey rules set out by their countrys' rules and laws (male, 39, private sector).

\section{Civics in Indonesia}

According to two interviewees, civics is interpreted in two contrasting ways. Firstly, that for an Indonesian citizen, civics is the right for Indonesian people to speak their mind and voice their opinion (female, 41, government). Subsequently to another perspective, "nationalism, heroism, patriotism defines civics" (male, 39, private sector).

\section{History in Indonesia}

In 1940, Indonesia fought bravely against the Dutch and the Japanese imperialists. However, the history of Indonesia began in 1945 when Indonesia declared independence from the Dutch colonizers for being under the rule of the King of the Netherlands for over 350 years, essentially regulating their rights and duties. These events mean a 'new struggle' for all citizens within the country and gives a chance for all to participate in every way possible (male, 39 , 
private sector). As many political parties and organisations emerged, the country has always been successfully led by its people as it is "very diverse, with many tribes, languages and religions" (female, 41, government). With the turbulence in the 1960s of the mass killings from the Communist Party (PKI), Suharto rose to power resulting in a "new order of government, economic development, poverty reduction, and corruption" (female, 16, student). By the 1990s, more participation was observed by the direct election and the new law of local governments which gave local citizens to decide on new developments. By 2006, local governments started opening up to public participation in politics encouraging government branches to have social media to showcase their plans. The year 2014 gave more power to local people in villages to increase public participation for the development of their villages to prioritize what they want to develop for the next 5 years etc, "However, this does not mean that corruption was diminished at all" (female, 39, junior researcher). "Since then we have achieved a lot and we should be proud," says another interviewee. "Since we have achieved a lot, therefore we should be proud. Many like to see Indonesia as a beacon of democracy, as they want to learn from us as we have a high rating from the last 20 years" (male, 41, non-governmental).

\section{Historical Event that helped shape civics in Indonesia}

Three separate struggles in three years shaped the results of what we have today in Indonesia. First, the independence of Indonesia in 1945. Secondly, Indonesia's mass killings targeting Communist Party (PKI) resulted in civil unrest. Thirdly, the mass violence in demonstrations for fighting against racial discrimination against Chinese Indonesians, subsequently resulting in civil unrest (male, 39, private sector). The end of Suharto's leadership 
resulted in people being sick and tired of his governing serving president for over 31 years, essentially asserting an authoritarian rule (female, 41, government). Furthermore, cyber laws were enforced which regulated laws if people behaved wrongly online regulating ombudsman officials to be able to enforce the law to stop online fraud, hate speech which applies for all accounts, business and personal. Despite it being a controversial law nowadays as it is being revised for legal drafting of the Constitution (female, 39, junior researcher).

\section{Suharto's leadership regime}

According to an interviewee, Suharto's authoritarian rule as president for over 31 years disabled citizens from freely expressing their opinion however for those who did were silenced. "From what I saw in the news/television, we were not free to express ourselves and our rights were much more limited" (female, 39, junior researcher). A majority of slave workers who were not treated fairly came to protest to the law enforcement however in the following days, they went missing. In 1990, a female labour worker who was the leader for the Independent Trade Union named Marsinah was murdered brutally after she expressed her opinion due to unequal pay. Subsequent to these murders, Suharto was accused of several human rights violations, therefore the United Nations Commission on Human Rights resolution 1993/97 expressed serious concern over allegations of serious human rights violations by the government of Indonesia establishing a human rights commission through the Presidential Decree of (No. 50 of 1993). The 1997 Asian economic crisis simulated violence and strikes so students, politicians, and citizens demanded Suharto to give up his power. The Constitution states that citizens can apply for jobs despite racism and discrimination against Chinese-Indonesians resulting in an 
environment less inclusive for Indonesians (female, 39, junior researcher). After his long ruling as president of 31 years, his downfall began and so did the new reformation. Despite this fact, his family is still on top of the "pyramid" today, and still helps rule Indonesia acting as the "behind the scene" people having been caught corrupting a lot of money 50 billion rph (female, 16, student).

Structure of the Indonesian State

The system of the Indonesian state follows the trials of a political structure. Consists of the 34 ministers, bureau leaders, head of commissions, and house of representatives. Also, the executive, legislative, and judiciary. In addition, non-governmental organisations exist as independent commissions which "solely work to implement the menders given by the laws" (male, 42, non-governmental). As we all know, the President has power to implement laws. However, following this in 1994-1995 around 28 years after Suharto's presidency, a new assembly of Indonesian representatives made new improvised civics laws constitutionally based on Netherlands' laws, giving Indonesians new rights to participate in Indonesian politics. They can join political parties and meet the threshold to move forward to become the governor/president (male, 39, private sector). According to an interviewee, President Joko Widodo listens to the voices of his fellow citizens as "he is more down to earth" (female, 16, student). Over the past few years, he has worked hard to improve infrastructure such as roads, bridges, trains and harbours, ultimately improving the lives of the civilians. Despite this, human resources are still the issue, lacking law enforcement results in people being ignored and doing things that they are not supposed to do. "Basically people working in those institutions. I can 
assure you we are always progressing, however, EDUCATION. Teach about responsibility, morality, in school, uni, institutional level, work. None of it will work in any country if the people don't know what they need to do or how to do it" (female, 41, government).

\section{Official Legal Instrument - Indonesia}

A majority of the interviewees agreed that the 1945 UUD Constitution of Indonesia with a Netherland based concept of laws with a couple of improvisations and amendments. Article 27 until article 34 are the basis of indonesian civics, "all Indonesians will go by these sets of laws in civics in the latest revised version" (male, 39, private sector). In addition, Pancasila was established by founding fathers who represented all the ethnic groups which included 5 principles. First, to believe in one god and only one god. Secondly, be civilised and fair to humanity, essentially how we should treat others as a citizen. Thirdly, the Unity of Indonesia. Fourth, fair and civilised deliberative processes among representatives. Finally, social fairness for all Indonesian citizens. "The way I see it, it is the basic spirit for every legislation that should be acquitted to all the stakeholders such as trials of politica, legislative, judiciary, president" (female, 39, junior researcher). In addition, the Youth Pledge of 1928 is an important document which states the civil duties an Indonesian must have become the basics of our country's civics at the time (female, 41, government).

\section{Political Participation}

Political participation means having the right to vote for your chosen member of parliament by the age of 17 . In Indonesia, people campaign their ideas and missions by being 
involved greatly with the people. Politicians move around the country and smaller villages to campaign their vision further encouraging civilians to participate in the election process. According to an interviewee, in the last 5 years, social media has been used greatly as a way to successfully campaign their work and their mission. Citizens may use their right to file a complaint for public service and participation by a system of politics called Ombudsman. Which guarantees that citizens' voices are heard by giving people voices and power, raising concerns, obliging an official to respond to your concerns as a citizen. "State apparatus commision, they do this law enforcement for any fraud, citizens can report it to a civil state apparatus commision or a website called lapor.go.id. It is managed by the commission's and bureau / state secretary and ministry of administrative bureaucratic reform. The reports are sent to the local government related to the specific complain. Efficiency that maintains complaints directed to them and the topic. Instagram can be used for ministries such as the minister of finance, to observe and publish her activities and the summary of the state budget. She would ask if they had this money and if you were a minister, "what would you do with the amount of the state budget?" "Despite the fact they don't consider all the opinions, it's an exercise for people to participate in improving the lives of Indonesian citizens" (female, 39, junior researcher). For example another popular student-led instagram account called @whatsupindonesia has been used to spread awareness and form opinions on news in Indonesia both in english and bahasa Indonesia (female, 16, student).

Public Participation for an Indonesian citizen 
For those who have the privilege of a higher education, participation may not be as important to them. "Overall it is quite important because it contributes to the government's effectiveness. An indicator published by the World Bank talks about the quality of the regulation and perception of corruption and how public relations and public policy address the problems that are felt by the citizens" (female, 39, junior researcher). "You should use your right to vote, because it will help determine the future of our country for the next 5 years" (female, 41, government). According to a younger interviewee, political participation is highly important for the younger generations as it helps them become more curious and aids the government to build on the recommendations and helpful tips from the public, "Every single voice matters" (female, 16 , student).

Importance of Political Participation for people to engage from an Indonesian citizen

"I believe that they should voice their opinion" (female, 39, junior researcher). A most likely consequence if they didn't voice their opinions the policies made cannot address the real problems of the country. Citizens should also be aware of their rights and what to discuss about, instead of just "rambling" about topics without actually knowing what the core problem is as it is for the betterment of this country (female, 41, government). According to another interviewee, "it all depends on whether the system is corrupt or not." If citizens think the system is not corrupt they would definitely go forward to engage themselves within politics. However, if the system is corrupt from social media, breaking news, or news outlets there'll be more political parties being caught for corruption by the police of the KPK (male, 39, private sector). Therefore discouraging many to engage in political participation. 


\section{Effect of Pandemic on Civics in Indonesia}

A few interviewees agreed that the Co-vid 19 pandemic has affected the lives of many. In Indonesia, it mainly affected the use of movement around the city and their obligations as a citizen . On what Indonesian students would call a "normal day", on a Monday morning, they would wake up at sunrise and begin getting ready for a long day at school, where they would later perform a physical ceremony showing their civil duties as a young Indonesian citizen by singing the national anthem and raising the Indonesian flag in front of the school (male, 39, private sector). Another perspective is that people are more vocal in expressing their opinion online from instagram accounts by government policies for example. As we need to limit our movement to contain the virus (female, 41, government), it can be observed from the unsuccessful implementations the government has done. Around April 2020, they planned to do training for unemployed people but the pandemic striked then people protested online since the training was not so optimal. As a result, they and researchers persisted for UCT Unconditional Cash Transfer to be implemented for people who have lost their job (female, 39, junior researcher).

\section{Civics in Retrospect}

In retrospect, civics has improved over the past 20 years as Indonesia as a whole is becoming more aware post new reformation and Sukarno's presidency. People start acknowledging their obligations to the country. Essentially, it has resulted in people discussing and talking and brainstorming about everything including civic duties (male, 39, private sector). 
Civics in Indonesia still has so much room for improvement as people love to critique and speak their minds as we will never learn if we are silent (female, 41, government). According to multiple interviewees, the government should focus more on younger generations as one side eases the learning process since younger generations are much more tolerant to the diversity of Indonesia compared to older generations (female, +-39 , junior researcher). Additionally, because they are the future (female, 16, student).

Civics in Indonesia by 2050

By 2050, there shall be two different perspectives for civics in Indonesia to result in. Firstly is for younger generations to strive for a better future, discipline and commitment (female, 15, student). Many of the interviewees looked towards a brighter future, stating that, "It is going to be much better than what we have now, the education will improve and social media's involvement has increased" (male, 39, private sector).

\section{Research Findings in Brazil}

What is civics?

The interviewees generally agreed that civics can be seen as the role of citizens revolving around the idea of participation. One interviewee clearly stated that civics entails the distribution of power, along with democracy (female, 38 , educator). 


\section{Civics in Brazil}

According to one interviewee, civics is greatly influenced by the Constituição da República Federativa do Brasil, which was "written very participatory and democratically" marking a "reaction to the period of authoritarianism and essentially reflects a dream of a more equal and just society" (female, 38, educator). Contrasting to other interviewees, civics is "a very new notion in the history of Brazil" which is still steadily building up (female, 54, educator).

\section{History in Brazil}

In the 16th century, many would describe the colonisation of the Portuguese as the invasion of Portugal. One interviewee stated, "If you were an indigenous person living in precolonial times you would not need to define citizenship, since you are living communally, you are already part of the community and already contributing as was expected" (female, 38 , educator). According to two interviewees, the only people "with a role were the white, rich aristocratic men in the government" along with "an interest of the colonial state" (male, 16, student) (female, 38, educator). Several agreed that "civism shall only be spoken about after the abolition of slavery in 1888" and "comes with time and modernity" during the "period of flourishment and economic development" (female, 54, educator) (female, 38, educator).

Historical Event that helped shape civics in Brazil 
Numerous interviewees mostly agreed that the military dictatorship in the 1960s led from the abolishment of slavery in 1888, to the Constituição do Brasil of 1988 which greatly helped shape civics in Brazil.

Describing The Period Between 1964-1985

The phase can be best described as "the period of censorship" where the military was in command as "very poorly experienced politicians" resulting in a "very repressive regime" (male, 16, student) (female, 38, educator). An interviewee stated the period was a traumatic experience which led people to "become aware of the importance of democracy and the right to vote" as "it was not a safe place to be since it was in detriment to people's opinions and voices" (male, 16, student) (female, 38, educator).

Structure Of The Brazilian State

The structure of the Brazilian state consists of three independent branches: executive, legislative, and judiciary, which all follow the Federal Constitution as the Supreme Law of Brazil. A President is newly elected every four year term and parties elect a new representative by coming to a solid agreement amongst themselves to have a set candidate/representative. According to an interviewee, Brazil can be seen as a generally decentralized government as it is very dependent on federal funds and divisions since, "federal funds are centralized then the state distributes within the municipal government." An interviewee states that as of now, "we are going through a commission of parliamentary inquiry against Bolsonaro's COVID-19 
management, which he is terrified of because he may suffer impeachment" (female, 38, educator). In addition, another interviewee openly agreed that, "the system is corrupt, especially in general the bureaucracy" (male, 16, student).

Official Legal Instrument - Brazil

Various interviewees generally acknowledged the Constituição do Brasil of 1988 as "the best set of papers which describes civics" which "goes into detail about everything" and further describes the result of "the period of dictatorship" in which, "every citizen has a right to know" (male, 16, student) (female, 38, educator) (female, 54, educator).

\section{Political Participation}

Nowadays, political participation can be seen in many forms. Firstly, in terms of direct participation, having the right to vote for your chosen member of parliament every four years, "Public participation can be seen through voting! Choosing our leaders consciously and effectively" (female, 54, educator). As well as efforts to implement change locally, "Like the Agenda 21, which could really help us with local politics, including diverse groups of citizens that gather to discuss the priorities of the locals, however has not been fruitful and left aside" Secondly, in terms of indirect participation is freedom of speech. Brazil is a country with citizens experiencing a past of "the period of authoritarianism" (male, 16, student), resulting in public demonstrations, social movements and the increased usage of social media engaging with 
the public sphere, which do not directly impact politics but could bring "attention or pressure" (female, 38, educator).

\section{Public Participation for a Brazilian Citizen}

For a Brazilian citizen, "Direct participation can make significant change. You may not like politics but it is selfish to refuse to talk about it" (male, 16, student). In addition, "If everyone knew the impact they could possibly have in decision making, it would be ideal in all aspects" In decision making, it is crucial that "there are not too many bureaucratic levels before the actual decision is made, people could lose themselves" (female, 38 , educator).

Importance of Political Participation for people to engage from a Brazilian citizen

Nowadays with the "polarisation of politics and the pandemic it is more than ever important for citizens to engage in politics despite your political preference" (male, 16, student). According to an interviewee, "Citizens should engage. However, before engaging they should know how much they can influence in politics and feel that they can influence. Need to know their engagement has results. System of politics should guarantee that citizens' voices are heard, an Ombudsman system because giving people voices and power, raising concerns, obliging someone to respond to your concerns. Actual results of complaints really feel good and empowering to see positive impacts. Technology has improved as we have all the tools in our hands" (female, 38, educator). 
Effect of Pandemic on Civics in Brazil

The interviewees generally agreed that due to the pandemic, it has negatively impacted the lives of many resulting in, "the loss and silence of many voices" (female, 38, educator). The significant change in lifestyle as you are not allowed to go out into the streets as "your decision to wear a mask or not could potentially result in a major impact of the death of another citizen" Additionally resulting in the loss of rights for many and the downfall of the economy, "The Brazilian Constitution emphasizes that work and jobs are one of the many important ways to be an active citizen, to contributing to the economy and being employed" Because of this, citizens don't have a job nor do they have income and therefore no way to participate. In regards to the government handling of the pandemic, "they don't even support the masks and social distancing, or at least they act like they do." It is clear that Bolsonaro "would have affected civics with or without the pandemic due to his governance which is one of authoritarian, violent and highly based on fake news coming from Whatsapp and Facebook" (male, 16, student) (female, 38, educator)

\section{Civics in Retrospect}

Brazil's democracy has been building gradually as it has been improving better off than 200 years ago, including a sense of citizens gaining rights and possibilities for the future. 
However civics in Brazil has been in breach. "Brazil is under the threat of not being under a full democracy," describes an interviewee who recognizes themselves as a conscious and active citizen of Brazil. Since the rise of Bolsonaro's presidency in 2018, many felt the threat of not being able to voice your own opinion freely or having democratic institutions being dismantled. For many years, he has shown traits that do not qualify as suitable for a president. For example, prior to his presidency, he was "kicked out as captain for improper conduct" (female, 38, educator). In addition, an indigenous woman was called to court after voicing her opinion about the government online despite the freedom of speech being protected by the Constituição $d a$ República Federativa do Brasil. Also, showing his clear support for chloroquine, a malaria drug, believed to be a CO-VID19 treatment without any proof of scientific evidence. Finally, his poor covid management with strong oppositions to lockdowns, social distancing measures and his failure to quickly secure vaccines (male, 16 , student).

Civics in Brazil by 2050

Civics in Brazil has been "a one step forward and two step backward process" (male, 16, student). Brazil is slowly but surely building its path to a full democracy through the exercise of voting, inspection, and respect for our differences despite always being under the threat of authoritarianism. With next year's election, "we may turn into a dystopian society Bolsonaro is re-elected" (male, 16, student). Another interviewee also describes, "anyone to enter the office as president will be far better than Bolsonaro" (female, 38, educator). It is granted that the future of the Brazilian government will revolve around a digital age with the fast advancement of technology, e-government, and social media. Brazilians are hopeful that the country will have 
challenges but institutions will keep working to guarantee a democratic space despite always being under the threat of authoritarianism. Numerous interviewees expressed optimistic viewpoints that the future of Brazil will survive with more voices being heard toward a future that is us as citizens treading a brilliant path for a Brazil that we all want (female, 54, educator).

\section{Conclusion}

As an Indonesian, I discovered civics can generally be best defined as the rights and civil duties surrounding the idea of participatory democracy. My main finding was that Indonesia and Brazil share some similarities regarding civics despite contrasting differences in terms of location and democracy. Firstly, their idea of civics revolves around the set constitutions, $\underline{1945}$ UUD Constitution of Indonesia and Constituição do Brasil of 1988. Followed by the rule of authoritarianism by Suharto for 31 years from 1967 to 1998 and the military dictatorship of 1964, after a coup d'état by the Brazilian Armed Forces, with the support from the United States government against President João Goulart. By the age of 17 and 16 in Indonesia and Brazil, respectively, many use their right to vote for their chosen members of government every four years. Contrasting to this, public participation may vary in certain ways. In Indonesia, citizens oftenly use social media or websites such as lapor.go.id through an Ombudsman system to express their complaints to the government. In Brazil, many of the efforts to implement change locally such as the Agenda 21 could really help with local politics including diverse groups of citizens that gather to discuss the priorities of the locals, which has not been fruitful and left aside. Indonesia being one of the most active democracies, Brazil shares similarities in terms of the structure of the government. Both consist of three independent/traditional branches: executive, legislative, and judiciary where a new president is elected every four years. However, 
we can observe that Brazil's government is generally centralized, highly focusing on federal funds and divisions following the end of the military dictatorship in 1985. Contrasting Indonesia's government which is generally decentralized as a result of a successful transition from an authoritarian to a democratic government further strengthening a free and fair election. Giving power to the Indonesians and back to the people by exceeding the dynamics of growing democracy. Furthermore, as the pandemic has affected the world, it has created significant changes in both Brazil and Indonesia which have brought unprecedented complications for the countries to achieve development goals. In Brazil, many observed the poor government's handling of the pandemic has resulted in the loss of many voices and rights of citizens following the decrease in public participation in civics. In Indonesia, the pandemic has created changes for the right to movement and daily lifestyle.

To conclude on the information I found, it was very intriguing to listen to the different perspectives of Indonesians and Brazilians from different age spectrums discussing their viewpoint on civics in their country. Some of the most knowledgeable information I learnt was from collecting data and writing this report such as learning that both Indonesia and Brazil had authoritarian rulings and that. Some of the challenges faced writing the report was that I mainly struggled to find suitable Brazilians to interview in the time frame in which I had to finish the report. I had five Indonesian interviewees and three Brazilian interviewees which do not correlate to each other. However, despite these previous difficulties, I still managed to successfully conduct 8 interviews which led me to obtain very detailed information about civics and complete the report perfectly. 